\title{
Study on the prevalence of anaplasmosis and efficacy of different antiprotozoal drugs in goats at district Mirpurkhas, Sindh-Pakistan
}

\author{
Muhammad Ismail Memon ${ }^{1}$, Riaz Ahmed Leghari ${ }^{1 *}$, Hamzo Khan \\ Kumbhar $^{1}$, Nazar Ali Korejo ${ }^{1}$, Mujeeb u Rehman Memon ${ }^{1}$, Saeed \\ Ahmed Soomro ${ }^{1}$, Jameela Soomro ${ }^{1}$, Saajida Parveen ${ }^{2}$ and Shiva Ram ${ }^{1}$ \\ 1. Faculty of Animal Husbandry and Veterinary Sciences, Sindh Agriculture University Tandojam-Pakistan \\ 2. Central Veterinary Diagnostic Laboratory, Tandojam-Pakistan \\ "Corresponding author'email: drriazleghari@yahoo.com
}

Citation

Muhammad Ismail Memon, Riaz Ahmed Leghari, Hamzo Khan Kumbhar, Nazar Ali Korejo, Mujeeb u Rehman Memon, Saeed Ahmed Soomro, Jameela Soomro, Saajida Parveen and Shiva Ram. Study on the prevalence of anaplasmosis and efficacy of different antiprotozoal drugs in goats at district Mirpurkhas, Sindh -Pakistan. Pure and Applied Biology.Vol. 8, Issue 2, pp1025-1032. http://dx.doi.org/10.19045/bspab.2019.80043

\begin{tabular}{llll}
\hline \hline Received: 24/12/2018 & Revised: 07/03/2019 & Accepted: 22/03/2019 & Online First: 28/03/2019 \\
\hline
\end{tabular}

\section{Abstract}

This study was conducted to determine the prevalence of Anaplasmosis and efficacy of different antiprotozoal drugs in goats around the Mirpurkhas. A total of 300 goats were examined for the occurrence of Anaplasmosis. Anaplasma marginale was the only species identified from all positive goats and the highest prevalence of Anaplasmosis was recorded in Samaro (30\%) and the lowest (8\%) in Sindhri, district Mirpurkhas. The overall prevalence of anaplasmosis was recorded at $13.33 \%$. The rate of infection was higher in females (17\%) compared to males (9\%). The age wise prevalence was recorded $14 \%$ in two years of age and $12 \%$ in 2 years and above of age. The most prominent clinical features in positive cases of anaplasmosis were recorded increased body temperature, respiration and pulse rate, with loss of condition and icterus. The disease positive animals were divided into four groups; A, B, C and D in order to determine the efficacy of different antiprotozoal drugs. The Imidocarb, Diminazine and Oxytetracycline drugs were administered to A, B and C groups respectively, on the standard dose by the recommendations of manufacturers. While the D group was kept as an untreated positive control. It was observed that maximum efficacy against Anaplasma marginale was achieved by the administration of Imidocarb (80\%), followed by Diminazine (60\%) and Oxytetracycline (30\%). All animals of the infected control group (D) were remained positive and shown the increasing intensity of the infection and one goat was died in control group D due to the severity of the infection.

Keywords: Anaplasmosis; Antiprotozoal drug's efficacy; Goats; Prevalence

\section{Introduction}

Goats are small ruminants and maintain an especially valuable ecological and economical place in Asian agriculture. The importance of goats with a variety of different breeds and the degree of their 
adaptation is a unique and wide range of distribution throughout the ecosystem [1]. About $90 \%$ of the world's goat population is found in developing countries. New Zealand, Australia, India, Pakistan and China are the major goat producing countries in the world [2]. In Pakistan, there are 68.4 million heads of a goat and they are producing annually $25.8,000$ tons of hair and 671,000 tons of mutton [3]. Hemoprotozoan diseases, especially Anaplasmosis, Trypanosomiasis, Babesiosis and Theileriosis are major impediments to the health and production of livestock farming [4]. However, epidemiological studies revealed that demographic, location and environmental factors affect the risk of infection.

The protozoan parasites are the major threat to the animal's health in tropical and subtropical areas of the world. Protozoan diseases have been remained economically important due to affecting national and international trade $[5,6]$. These are also responsible for various degrees of morbidity, mortality and economic losses [7]. A.marginale, a subspecies with high pathogenicity has been proven capable of infecting goats [8]. Clinical signs in infected goats are reported as fever, weight loss, anorexia, hematuria, anemia and icterus [9]. The most effective method to control the parasitic diseases is through the strategic use of drugs that are available in the market, however, they are expensive and have toxic side effects, marginal efficacy and drugresistant [10]. Sometimes animals survive after a long convalescent period without treatment, but others may develop renal failure and shock which leads to death. Generally, anaplasmosis in goat is diagnosed on the basis of clinical signs and blood smears examination [11].

There was no comprehensive study conducted on the prevalence of anaplasmosis and efficacy of antiprotozoal drugs in goats.
Therefore, this study was designed to determine the prevalence of anaplasmosis and to evaluate the efficacy of different antiprotozoal drugs in goats of Mirpurkhas Sindh, Pakistan.

\section{Materials and methods Study area}

Mirpurkhas is situated in the east of Sindh province and it is the fourth largest city of the province with an estimated population of 488,590 . It comprises of many villages that depend on their livelihood on the rearing of small ruminants especially goats [3].

\section{Collection of samples}

A total, 300 goats of all ages and of either sex were randomly selected for the study. The blood smears were prepared for the examination and diagnosis of anaplasmosis in selected goats of Mirpurkhas.

\section{Blood smears}

Blood smears were made randomly from each goat flock depending on the number of goats and the history of the animals with weakness, anemia, inappetence and presence of the ticks on the different parts of the body. The Ear was cleaned with spirit swab before the puncturing ear vein and blood smears from each animal were prepared by using a disposable $23 \mathrm{G}$ needle. From each animal, 03 thick and 03 thin blood smears were prepared between 12 PM to 5 PM according to the procedure described by Tick Fever Research Center, Queensland [12].

\section{Thin blood smears preparation}

Thin smears were prepared by puncturing ear vein with a sterile needle to obtain a small quantity of the blood for the preparation of blood smears.

1. A drop of blood not larger than a pin's head was placed at the center of the slide.

2. A spreader slide at an angle of $35^{\circ}$ was placed in contact with the drop of blood then pushed gently to down till the thin blood smear was prepared.

3. Then, the slide was dried and fixed immediately in $100 \%$ methyl alcohol. 
4. All slides were properly labeled with a permanent marker, kept in a slide box and brought to the laboratory for further process.

\section{Thick blood smears}

Thick blood smears were prepared by placing a drop of blood on the center of the slide. Then at the angle of $45^{\circ}$, a spreader slide was pushed down gently to prepare thick smears. The prepared thick smears were fixed as done for thin smears and processed to the laboratory.

\section{Staining of the blood smears}

The staining procedure for all slides was carried out by the procedure as suggested by Chatterjee [13].

\section{Giemsa's staining}

Giemsa solution (Midiline chemical division Merck, Darmstadt, Germany) prepared bottles were purchased from the market. Slides were kept at horizontal on slide frame and few drops of Giemsa stain were poured on and then left for 15 minutes. Then, slides were gently washed in running tap water and kept upright position until slides dried. Now, these slides were ready for microscopic examination.

\section{Microscopic examination and} Identification of blood protozoa

All thin blood smear slides were examined under binocular electric microscope oil emersion 100x- objective lens. The Anaplasma spp. were identified and confirmed with the help of the key developed by Adam [14].

\section{Therapeutic trials}

Identified infected goats showing clinical signs were divided into four groups A, B, C and D (Control group), and each group was consisting of ten animals. The efficacy of three antiprotozoal drugs with the recommended dose (Imidocarb $0.1 / \mathrm{kg}$ body weight intramuscular, Diminazine $0.3 \mathrm{ml} / \mathrm{kg}$ body weight intramuscular and Oxytetracycline $1 \mathrm{ml} / \mathrm{kg}$ body weight intramuscular) was evaluated against positively infected goats. The blood smears were prepared from the infected cases after the treatment on day $14^{\text {th }}$ and $30^{\text {th }}$ and in positive cases, the $2^{\text {nd }}$ and $3^{\text {rd }}$ booster doses of treatment were given accordingly to check the efficacy of drugs, as shown in (Table 1).

\section{Results}

The study was randomly carried on 300 goats from different areas in and around Mirpurkhas. Data shows the overall prevalence rate of $13.33 \%$. The highest prevalence rate $(30 \%)$ of anaplasmosis was recorded in Taluka Samaro and the lowest $(8 \%)$ in Taluka Sindhri (Table 2).

In (Table 3) A. marginale was the only species identified as a small, round dark red inclusion body in the margin of Red blood cells similarly with the same characteristics as described by Urquhart [15]. Animals with anaplasmosis positive blood smears had shown clinical signs of increased body temperature, respiration, heart rates (Table $4)$, inappitance, ictrus and mild lymph nodes enlarged (Table 5).

\section{Prevalence}

As depicted in (Table 6), the gender-wise prevalence rate of Anaplasmosis as 9\% and $17 \%$ in male and female goats respectively.

\section{Age wise prevalence}

The age wise prevalence of anaplasmosis was observed as $14 \%$ in goats of up to 2 years of age and $12 \%$ in above than 2 years of age (Table 7).

\section{Drug Efficacy}

The drug efficacy was evaluated on the basis of the disappearance of the clinical signs and the absence of Anaplasm marginale from examined blood smears after the treatment. The Table 7 indicates the efficacy of antiprotozoal drugs against Anaplasmosis in infected goats. The results showed the efficacy of $80 \%, 60 \%$ and $30 \%$ with Imidocarb, Diminazine and Oxytetracycline, respectively, (Table 8). However, the efficacy showed that two animals by Imidocarb, four animals by Diminazine and 
seven animals by Oxytetracycline did not recover as shown in (Table 9).

Control group
All control group animals (Group D) infected with Anaplasmosis remained positive during the study period (Table 10), however after 30 days one goat expired.

Table 1. Drug names, dosage and routes of administration

\begin{tabular}{|c|c|c|c|c|}
\hline $\begin{array}{c}\text { S. } \\
\text { No. }\end{array}$ & Drug & Trade name & $\begin{array}{c}\text { Dosage and } \\
\text { administration }\end{array}$ & Manufacturer \\
\hline 1. & $\begin{array}{c}\text { Imidocarb di } \\
\text { propionate } \\
(120 \mathrm{mg} / \mathrm{ml})\end{array}$ & Imizol & $\begin{array}{c}0.1 / \mathrm{kg} \text { body weight } \\
\text { intramuscular }\end{array}$ & ICI, Pakistan \\
\hline 2. & $\begin{array}{c}\text { Diminazine di } \\
\text { aceturate }(35 \mathrm{mg} / \mathrm{ml})\end{array}$ & Diminazene & $\begin{array}{c}0.3 \mathrm{ml} / \mathrm{kg} \text { body weight } \\
\text { intramuscular }\end{array}$ & $\begin{array}{c}\text { Star Laboratories } \\
\text { (Pvt) Lahore, } \\
\text { Pakistan }\end{array}$ \\
\hline 3. & $\begin{array}{c}\text { Oxytetracycline } \\
(200 \mathrm{mg} / \mathrm{ml})\end{array}$ & $\begin{array}{c}\text { Rasomycin } \\
\text { LA }\end{array}$ & $\begin{array}{c}1 \mathrm{ml} / 10 \mathrm{~kg} \text { body weight } \\
\text { intramuscular }\end{array}$ & $\begin{array}{c}\text { Star Laboratories } \\
\text { (Pvt) Lahore, } \\
\text { Pakistan }\end{array}$ \\
\hline
\end{tabular}

Table 2. The Taluka-wise prevalence rate of Anaplasmosis

\begin{tabular}{|c|c|c|c|c|}
\hline $\begin{array}{c}\text { S. } \\
\text { No. }\end{array}$ & Name of Taluka/locality & $\begin{array}{c}\text { No: of Animals } \\
\text { examined }\end{array}$ & $\begin{array}{c}\text { No: of Animals } \\
\text { infected }\end{array}$ & $\begin{array}{c}\text { Prevalence } \\
\text { rate (\%) }\end{array}$ \\
\hline $\mathbf{1}$ & $\begin{array}{c}\text { Kot Ghulam } \\
\text { Muhammad }\end{array}$ & 50 & 06 & 12 \\
\hline $\mathbf{2}$ & Samaro & 50 & 15 & 30 \\
\hline $\mathbf{3}$ & Hussain Bux & 50 & 05 & 10 \\
\hline $\mathbf{4}$ & Sindhri & 50 & 04 & 08 \\
\hline $\mathbf{5}$ & Sahab Belaro shakh & 50 & 05 & 10 \\
\hline $\mathbf{6}$ & Jhudo & 50 & 05 & 10 \\
\hline & Total (\%) & 300 & 40 & 13.33 \\
\hline
\end{tabular}

Table 3. Anaplasma marginale spp. identified from goats

\begin{tabular}{|c|c|c|c|c|}
\hline $\begin{array}{c}\text { S. } \\
\text { No. }\end{array}$ & Species identified & $\begin{array}{c}\text { Total number of } \\
\text { animals } \\
\text { examined }\end{array}$ & $\begin{array}{c}\text { No: of animals } \\
\text { infected }\end{array}$ & $\begin{array}{c}\text { Prevalence rate } \\
(\boldsymbol{\%})\end{array}$ \\
\hline 1 & $\begin{array}{c}\text { Anaplasma } \\
\text { marginale }\end{array}$ & 300 & 40 & 13.33 \\
\hline
\end{tabular}

Table 4. Body temperature, pulse rate and respiration rate in infected goats

\begin{tabular}{|c|c|c|c|}
\hline & Body temperature in ${ }^{\mathbf{0}} \mathbf{F}$ & Heart rate/ minute & Respiration rate/ minute \\
\hline Mean & 105.2 & 112 & 84 \\
\hline SD & 2.22 & 10.88 & 8.22 \\
\hline Normal $^{*}$ & $102-103$ & $70-90$ & $10-30$ \\
\hline
\end{tabular}

*Rodostitiset al. (2002) 
Table 5. Major clinical signs observed in infected goats

\begin{tabular}{|c|c|}
\hline Clinical signs & Major observations \\
\hline Appetite & Inappetence \\
\hline Lacrimation & Absent \\
\hline Body condition & Slightly thin \\
\hline Nasal discharge & Mild \\
\hline Dehydration & Normal \\
\hline Body coat & Normal dry \\
\hline Mucous membrane color & Mild \\
\hline Muscle tremors & Mild enlarged \\
\hline Lymph node & Constipation/dry feces \\
\hline Defecation & Bright yellow \\
\hline Urine & \\
\hline
\end{tabular}

Table 6. Gender wise prevalence rate of anaplasmosis

\begin{tabular}{|c|c|c|c|}
\hline Sex & $\begin{array}{c}\text { No. of animal } \\
\text { examined }\end{array}$ & $\begin{array}{c}\text { No. of animals } \\
\text { infected }\end{array}$ & Prevalence percentage (\%) \\
\hline Male & 150 & 14 & $9 \%$ \\
\hline Female & 150 & 26 & $17 \%$ \\
\hline
\end{tabular}

Table 7. Age-wise prevalence of Anaplasmosis

\begin{tabular}{|c|c|c|c|}
\hline Age group & $\begin{array}{c}\text { No. of animals } \\
\text { examined }\end{array}$ & $\begin{array}{c}\text { No. of animals } \\
\text { infected }\end{array}$ & $\begin{array}{c}\text { Prevalence rate } \\
(\boldsymbol{\%})\end{array}$ \\
\hline Up to 2 years & 150 & 22 & $14 \%$ \\
\hline Above than 2 years & 150 & 18 & $12 \%$ \\
\hline
\end{tabular}

Table 8. Efficacy percentage of imidocarb, diminazine and oxytetracycline against anaplasma

\begin{tabular}{|c|c|c|c|c|}
\hline Group & Drugs & $\begin{array}{c}\text { No. of animals } \\
\text { treated }\end{array}$ & $\begin{array}{c}\text { No. of animals } \\
\text { recovered }\end{array}$ & Efficacy (\%) \\
\hline A & Imidocarb & 10 & 08 & 80 \\
\hline B & Diminazine & 10 & 06 & 60 \\
\hline C & Oxytetracycline & 10 & 03 & 30 \\
\hline D & Control group & 10 & 00 & 00 \\
\hline
\end{tabular}

Table 9. Efficacy of imidocarb, diminazine and oxytetracycline against $A$. marginale

\begin{tabular}{|c|c|c|c|c|}
\hline \multirow{2}{*}{ Groups } & $\begin{array}{c}\text { Drugs } \\
\text { (Brand Name) }\end{array}$ & Age & $\begin{array}{c}\text { Animal } \\
\text { recovered }\end{array}$ & Remarks \\
\hline \multirow{2}{*}{$\mathrm{A}$} & \multirow{2}{*}{ Imidocarb } & $3 \mathrm{~m}-5 \mathrm{y}$ & $08 \mathrm{M} / \mathrm{F}$ & Complete recovery \\
\cline { 3 - 5 } & \multirow{2}{*}{$\mathrm{B}$} & $1 \mathrm{y}$ & $02 \mathrm{M} *$ & No recovery \\
\hline \multirow{2}{*}{$\mathrm{C}$} & \multirow{2}{*}{ Oxyminazine } & $3 \mathrm{~m}-5 \mathrm{y}$ & $06 \mathrm{M} / \mathrm{F}$ & Complete recovery \\
\cline { 3 - 5 } & $3 \mathrm{~m}-5 \mathrm{y}$ & $04 \mathrm{M} / \mathrm{F}$ & No recovery \\
\hline $\mathrm{D}$ & Control & $3 \mathrm{~m}-5 \mathrm{y}$ & $03 \mathrm{M} / \mathrm{F}$ & Complete recovery \\
\cline { 3 - 5 } & $3 \mathrm{~m}-5 \mathrm{y}$ & $07 \mathrm{M} / \mathrm{F}$ & No recovery \\
\hline
\end{tabular}

$\mathrm{m}=$ months, $\mathrm{y}=$ years, $\mathrm{M}=$ male and $\mathrm{F}=$ female $*$ one goat died in this group 
Table 10. Days wise efficacy of imidocarb, diminazine and oxytetracycline in anaplasmosis in goats

\begin{tabular}{|c|c|c|c|c|c|c|c|c|c|c|c|c|}
\hline \multirow{4}{*}{ Goat No. } & \multirow{2}{*}{\multicolumn{3}{|c|}{$\begin{array}{c}\text { Group-A } \\
\text { Imidocarb }\end{array}$}} & \multirow{2}{*}{\multicolumn{3}{|c|}{$\begin{array}{c}\text { Group-B } \\
\text { Diminazine }\end{array}$}} & \multicolumn{3}{|c|}{ Group-C } & \multicolumn{3}{|c|}{ Group-D } \\
\hline & & & & & & & \multicolumn{3}{|c|}{ Oxytetracycline } & \multicolumn{3}{|c|}{$\begin{array}{c}\text { Non-medicated } \\
\text { (control) }\end{array}$} \\
\hline & \multicolumn{3}{|c|}{ Days } & \multicolumn{3}{|c|}{ Days } & \multicolumn{3}{|c|}{ Days } & \multicolumn{3}{|c|}{ Days } \\
\hline & 1 & 15 & 30 & 1 & 15 & 30 & 1 & 15 & 30 & 1 & 15 & 30 \\
\hline 1 & + & + & - & + & + & - & + & + & - & + & + & + \\
\hline 2 & + & + & - & + & + & - & + & + & - & + & + & + \\
\hline 3 & + & + & - & + & + & - & + & + & - & + & + & + \\
\hline 4 & + & + & - & + & + & - & + & + & + & + & + & + \\
\hline 5 & + & + & - & + & + & - & + & + & + & + & + & + \\
\hline 6 & + & + & - & + & + & - & + & + & + & + & + & + \\
\hline 7 & + & + & - & + & + & + & + & + & + & + & + & + \\
\hline 8 & + & + & - & + & + & + & + & + & + & + & + & + \\
\hline 9 & + & + & - & + & + & + & + & + & + & + & + & + \\
\hline 10 & + & + & + & + & + & + & + & + & + & + & + & + \\
\hline Efficacy (\%) & 0 & 0 & 80 & 0 & 0 & 60 & 0 & 0 & 30 & 0 & 0 & 0 \\
\hline
\end{tabular}

$+=$ indicates the presence of Anaplasmosis in the blood

- =indicates the absence of Anaplasmosis in the blood

Discussion

This study was carried out on randomly selected 300 goats of district Mirpurkhas. The overall prevalence of anaplasmosis was $13.33 \%$. The prevalence of Anaplasmosis was recorded the highest $30 \%$ in samaro and $8 \%$ as the lowest in Sindhri. This is in agreement with the results reported from Cyprus [16], who recorded a prevalence of Anaplasmosis $18 \%$ in goats. There was also a recorded prevalence of Anaplasmosis as $13.89 \%$ and $8.33 \%$ in sheep and goats respectively, from Khyber Pakhtunkhwa, Pakistan [17].

The gender wise prevalence rate of Anaplasmosis in goats was recorded as (9\%) and $(17 \%)$ in male and female goats respectively. The findings of this study are in contrast with Lee [18], who reported that a higher prevalence of Anaplasmosis in male goats $(52.14 \%)$ as compared to females $(47.85 \%)$. This difference may be due to the increased opportunities of exposure to ticks carrying Anaplasmaspp.in a whole herd.
The age wise prevalence of Anaplasmosis observed in our study was (14\%) in up to 2 years of age whereas, above than 2 years of age was observed (12\%). Arunconcluded that the overall incidence of anaplasmosis was found $9.2 \%$ in sheep above 2 years of age [19]. Similar results of anaplasmosis in goat were observed by Lee [18], who reported $4.9 \%$ and $9.5 \%$ in aged $<1$ year and $\geq 1$ year, respectively. The variation in prevalence percentage might be due to the difference in goat breed, management, feeding and housing as well as the age group of animals used in the study.

Goats, which were found positive had shown the clinical signs of fever, inappetence and constipation (dry feces), anemia (pale conjunctiva and oral mucous membrane), lethargy, rough coat, early tiredness and loss of the body weight before the treatment, while all goats which recovered had shown gross improvement and activeness and weight gain. These clinical signs are in close agreement with the 
Chochlakis [16] and Dold and Cocks [20], who observed the similar clinical signs of Anaplasmosis in infected and recovered goats in Cyprus and South Africa, respectively.

The A. marginale was the only species identified from all positive samples which is in close agreement with the Sajid [21] and Talat [22], who also identified the $A$. marginale causing the Anaplasmosis in goats in Pakistan.

Results of the present study revealed that the efficacy of Imidocarb, Diminazine and Oxytetracycline was $80 \%, 60 \%$ and $30 \%$ respectively. It was observed that maximum efficacy against anaplasmosis was recorded with Imidocarb and Diminazine, while the minimum efficacy was recorded with Oxytetracycline; these results are in the closed agreement described by Zaugg [23].

In control infected group (Group-D), one goat with Anaplasmosis was expired while the intensity of the clinical signs (Anemia, anorexia) was changed from moderate to severe within 30 days and all positive goats showed health deterioration by the severity of the infection. Further, we found that control group (D) anaplasma positive goats (day $30^{\text {th }}$ ) deteriorated health with an increase in the severity of the clinical signs which were similar as previously reported by Chakrabarti [24].

\section{Conclusion}

The anaplasma infection is an endemic infection present in all goat farming areas of district Mirpurkhas. The rate of infection was higher in the female in comparison to male animals. The higher Anaplasmosis cases were observed in goats of two years than other age groups. All infected goats treated with Imidocarb @ 0.1 $\mathrm{ml} / \mathrm{kg}$ body weight i $/ \mathrm{m}$ and Diminazine $0.3 \mathrm{ml} / \mathrm{kg}$ body weight $\mathrm{i} / \mathrm{m}$ showed good response against Anaplasma infection in goats.

\section{Authors' contributions}

MI Memon conceived and designed the project and S Ram performed the experiment. HK Kunbhar and NA Korejo analyzed the data while, RA Leghari contributed to materials, tools and field supervision. MR Memon, SA Soomro and S Parveen helped in data analysis and proofreading of the manuscript.

\section{Acknowledgments}

The authors are obliged to the Higher Education Commission of Pakistan for providing financial assistance to conduct this study. The authors also acknowledge the laboratory and farm staff for their assistance and cooperation.

\section{References}

1. Devendra C (1996). Opportunities for increasing the economic contribution of small ruminants in Asia. In: LF Le Jambre and MR Knox (eds) "Sustainable parasite control in small ruminants". Bogor, Indonesia. ACIAR Proceedings 74: 27-32.

2. Khan MA, Hussain SN, Bahadar S, Anwar A \& Imtiaz AS (2008). An outbreak of anaplasmosis in goats in district Chitral, NWFP, Pakistan. J Agri Bio Sci 13 (2): 19-22.

3. GOP (2016). Economic Survey of Pakistan (2015-16). Economic Wing, Finance Division, Government of Pakistan, Islamabad.

4. Rajput ZI, Song-Hua HU, Arijo AG, Habib A \& Khalid M (2005). Comparative study of anaplasma parasites in tick carrying buffaloes and cattle. J Zhejiang Uni Sci B 6(11): 10571062.

5. Uilenberg G (2001). Babesiosis. In: Service, MW, Ed., Encyclopedia of Arthropod-Transmitted Infections of Man and Domesticated Animals. CABI Publishing, Wallingford, pp. 53-60.

6. Bishop R, Musoke A, Morzaria S, Gardner M \& Nene V (2004). Theileria: 
intracellular protozoan parasites of wild and domestic ruminants transmitted by ixodid ticks. Para J 129: 271-283.

7. Kettle DS (1995). Medical and Veterinary Entomology, $2^{\text {nd }}$ Ed. Colset Pte Ltd, Singapore.

8. Nanda YP, Chatterjee A, Purohit AK, Diallo A, Innui $\mathrm{K}$, Libeau RNG, Thevasagayam GJA, Bruning A, Kiching RP, Anderson J, Barrett T \& Taylor WP (2013). The isolation of anaplasmosis from Northern India. Vet Micro 51(3-4): 207-216.

9. Rubaire-Akiiki C, Okello-Onen J, Nasinyama GW, Vaarst M, Kabagambe EK, Mwayi W, Musunga D \& Wandukwa W (2004). The prevalence of serum antibodies to tick-borne infections in Mbale district, Uganda: The effect of agroecological zone, grazing management and age of cattle. J Ins Sci 4(8): 1-8.

10. Chapman AC, Minet CL, Goff G, Berhe E, Albina G \& Barrett LT (2007). The threat of anaplasmosis: progress in vaccine development for disease control. Vacc 25: 5591-5597.

11. Siddiki A, Das S, Roy K, Masuduzzaman MD, Sikder S, Hassan MM, Zsiddiki A \& Hossain MA (2010). Prevalence of Hemo-protozoan diseases in cattle population of Chittagong Division, Bangladesh. Pak Vet J 32(2): 221-224.

12. TFRC -Tick Fever Research Center (1996).Tick Fever and Disease Diagnosis Queensland, Australia: Department of Primary Industries.

13. Chatterjee KD (1980). Parasitology. $12^{\text {th }}$ Ed. Chatterjee medical publication Calctta.

14. Adam KM, Paul GJ \& Zaman V (1971). Medical and Veterinary Protozology (An illustrated guide), revised edition, Longman group limited, Great Britain.

15. Urquhart GM (1996).Veterinary Parasitology Second Edition, Black well Science. Ltd. London.

16. Chochlakis D, Ioannou I, Sharif L, Kokkini S, Hristophi N, Dimitriou T, Tselentis Y \& Psaroulaki A (2009). Prevalence of Anaplasma sp. in goats and sheep in Cyprus. Vector Borne and Zoo Dis 9 (5): 457-463.

17. Nasreen A, Lal C, Gadahi JA, Mirbahar KB \& Memon MI (2016). Efficacy of various antiprotozoal drugs on bovine babesiosis, anaplasmosis and thileriosis. Vet World 3: 272-274.

18. Lee MM, Hussain I, Arshad M \& Muhammad G (2013). Occurrence of anaplasmosis in five districts of Punjab, Pakistan. Pak Vet J 33(2): 165-169.

19. Arun K (2014). A report on the incidence of Anaplasmaovis infection in sheep. Int J Food Agri \& Vet Sci 40: 71-72.

20. Dold A \& Cocks M (2001). Traditional veterinary medicine in the Alice district of the Eastern Cape Province, South Africa: research in action. Safr J Sci 97: 375-379.

21. Sajid MS, Iqbal Z, Nisar M, Khan R \& Muhammad G (2008). Point prevalence of hard ticks (Ixodids) infesting domestic ruminants of lower Punjab, Pak Int $J$ Agri \& Bio 10: 349-351.

22. Talat R, Khanum $\mathrm{T} \&$ Hayat A (2005). Studies on mammalian haematozoan parasites of NWFP Pakistan. Pak J Bio Sci 8: 726-729.

23. Zaugg JL (2009). Babesiosis. In: Smith, B.P. (Eds): Large Animal Internal Medicine. Mosby, Elsevier, St. Louis, p 1157.

24. Chakrabarti A (1996). A Text Book of Preventive Veterinary Medicine. $1^{\text {st }}$ Edition. 